\title{
THE NATIONAL AIR POLLUTION CONTROL PROGRAMME IN POLAND - SELECTED LEGAL ISSUES
}

\author{
Ewa Radecka*
}

\begin{abstract}
This article focuses on Poland's obligations arising from Article 6 of Directive (EU) 2016/2284 of the European Parliament and of the Council of 14 December 2016 on the reduction of national emissions of certain atmospheric pollutants,

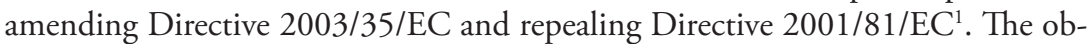
jective of the article is to present legal solutions adopted in the National Air Pollution Control Programme (further referred to as the NAPCP) in Poland. This is preceded by an analysis of this document in the context of other legal instruments for environmental protection, and an evaluation of its effectiveness. The author also refers to the legal nature of this document and indicates the consequences of late and incorrect implementation of the Directive.

The paper uses the formal and dogmatic method, based on the examination of the texts of legal acts and views expressed by legal academics and commentators as well as judicial decisions. The aim of its use was mainly to make a review of the provisions concerning the examined issue and their interpretation.
\end{abstract}

Key words: air, air protection, NEC Directive

Ph.D., Assistant Professor, Faculty of Law and Administration, Institute of Law, University of Silesia in Katowice; ewa.olejarczyk@us.edu.pl, ORCID: 0000-0003-4669-3327.

OJ L 344, 17.12.2016, pp. 1-31; further: the NEC Directive. Pursuant to Article 22 thereof, the Directive entered into force on 31 December 2016, with member states being obliged to draw up and provide their first national air pollution control programmes to the Commission by 1 April 2019. 


\section{INTRODUCTION}

The subject matter of this article appears exceptionally interesting not just from the research perspective. The importance of air protection, in Poland in particular, is beyond obvious. The issue attracts considerable attention of the media and citizens, whose awareness of air protection is increasing, also thanks to reports presented by the World Health Organisation (further: the WHO) ${ }^{2}$, European Commission ${ }^{3}$ or the Supreme Audit Office ${ }^{4}$. Moreover, one cannot help but feel that the issue of air protection is receiving considerable attention not just in the case-law of the CJEUs,

2 The latest ones show the scale of the problem facing Poland. The list of Europe's 50 most polluted cities, according to the $\mathrm{WHO}$ data, is topped by two Bulgarian cities (Vidin and Dimitrovgad), however as many as 36 out of 50 cities ranked are located in Poland (November 5, 2019, https://unearthed.greenpeace.org/2018/05/02/air-pollution-cities-worst-global-data-world-health-organisation/).

3 As the "Environmental Implementation Review 2019. Country Report - Poland" shows, "there has been no progress on improving air quality. Limit values for particulate matter, benzo(a)pirene and nitrogene oxides continue to be exceeded" [emphasis added: Ewa Radecka] (November 5, 2019, https://ec.europa.eu/environment/eir/pdf/report_pl_en.pdf).

4 Environmental protection against pollution. 2014-2017 (First half). Supreme Audit Office, Warsaw, September 2018 (November 6, 2019, https://www.nik.gov.pl/kontrole/P/17/078/): "high level and large scale of air pollution are indicative, in particular, of a lack of effectiveness in the fulfilment of duties of public authorities, arising from Article 68(4) and Article 74(2) of the Constitution of the Republic of Poland, as well as of the failure to accomplish the environmental protection goals set in Article 85 of the Environmental Protection Law. According to the Supreme Audit Office, with only a few exceptions, this resulted from insufficient activity on the part of public entities at each level of operation (national, regional, local), as well as from inadequate coordination and, what follows, failure to ensure coherence of actions carried out within the elaborate structure of the air protection system. Such conditions are not conducive to an effective expenditure of public funds for air protection. According to NIK, such omissions and improper actions on the central, voivodship and communal levels - bear a serious risk of not achieving results leading to achieving air quality standards applicable in the EU. Therefore, the probability of approaching the concentrations of some substances in the air in Poland to a significantly more restrictive levels resulting from WHO recommendations decreases even more, whereas this is the actual objective arising from general assumptions of EU policy in the area of environment protection and provisions of national strategy (NPAP)".

5 Examples include judgment of the Court of 5 April 2017 in Case C488/15, Commission v Bulgaria (EU: C:2017:267). 
but also in the work of the Commission ${ }^{6}$, and that it constitutes an important element of EU's policy ${ }^{7}$. Furthermore, one cannot overlook the fact that Poland is becoming a disgraceful favourite of the Court also, or perhaps most of all, in cases involving the natural environment ${ }^{8}$.

6 The Commission launched proceedings against Belgium, the Czech Republic, Germany, Greece, Spain, France, Hungary, Italy, Latvia, Portugal, Romania, Sweden, Slovakia and Slovenia (for breaches of obligations related to PM10). Furthermore, there are 13 ongoing proceedings due to nitrogen dioxide exceedances (Austria, Belgium, the Czech Republic, Germany, Denmark, France, Spain, Hungary, Italy, Luxembourg, Poland, Portugal, the United Kingdom).

The Commission has made the decision to refer France, Germany, Hungary, Italy, Romania and the United Kingdom to the Court of Justice of the EU for failing to respect agreed air quality limit values and for failing to take appropriate measures to keep exceedance periods as short as possible.

Data quoted after a press release of the European Commission of 17 May 2018: "Air quality: Commission takes action to protect citizens from air pollution" (November 5, 2019, https://ec.europa.eu/commission/presscorner/detail/en/IP_18_3450).

7 As a side note, it should be noted that EU legislation in the area of environmental protection is quite copious and includes e.g. directives:

1. Directive 2008/50/EC of the European Parliament and of the Council of 21 May 2008 on ambient air quality and cleaner air for Europe (OJ L 152, 11.6.2008, pp. 1-44);

2. Directive (EU) 2015/2193 of the European Parliament and of the Council of 25 November 2015 on the limitation of emissions of certain pollutants into the air from medium combustion plants (OJ L 313, 28.11.2015, pp. 1-19);

3. Directive 2010/75/EU of the European Parliament and of the Council of 24 November 2010 on industrial emissions (integrated pollution prevention and control) (OJ L 334, 17.12.2010, pp. 17-119);

4. Directive 2009/28/EC of the European Parliament and of the Council of 23 April 2009 on the promotion of the use of energy from renewable sources and amending and subsequently repealing Directives 2001/77/EC and 2003/30/EC (OJ L 140, 5.6.2009, pp. 16-62);

5. Directive 2001/81/EC of the European Parliament and of the Council of 23 October 2001 on national emission ceilings for certain atmospheric pollutants (OJ L 309, 27.11.2001, pp. 22-30);

6. Directive 2001/80/EC of the European Parliament and of the Council of 23 October 2001 on the limitation of emissions of certain pollutants into the air from large combustion plants (OJ L 309, 27.11.2001, pp. 1-21).

8 Some of the recent judgments involve the following cases:

- C-192/18, concerning the failure of a member state to fulfil obligations; establishment of different retirement ages for men and women holding the position of judge of the ordinary Polish courts or of the Sąd Najwyższy (Supreme Court, Poland) 
An important element of the context, explaining certain delayed measures of the Republic of Poland in the area of national legislation is Poland's complaint against the European Parliament and the European Commission on the NEC directive, filed on 10 March 2017 based e.g. a statement of the Poland's Ministry of the Environment that the reduction of ammonia emissions, as provided for in the NEC directive "will essentially boil down to imposing further burdens on Poland's small-scale agriculture, which the Ministry opposes". The case closed with a CJEU judgment of 13 March 2019', in which the Court did not uphold the arguments of the applicant and dismissed the action in its entirety.

For the purposes of this article, I have made references to the key instruments of air protection ${ }^{10}$, crucial from the perspective of the topic discussed herein ${ }^{11}$.

or that of public prosecutor in Poland (Judgment of the CJEU of 5 November 2019; ECLI:EU:C:2019:924);

- C-127/17, in which Poland is accused of violating the EU directive establishing the limit values for weights and dimensions for certain road vehicles (Judgment of the CJEU of 21 March 2019; ECLI:EU:C:2019:236);

- C-336/16, connected with air protection in Poland (judgment of the CJEU of 22 February 2018; ECLI:EU:C:2018:94);

- C-441/17, concerning felling of trees in "Puszcza Białowieska" Natura 2000 site (judgment of the CJEU of 17 April 2018; ECLI:EU:C:2018:255);

- C-526/16, concerning assessment of the effects on the environment of drilling to locate or search for shale gas (judgment of the CJEU of 31 May 2018; ECLI:EU:C:2018:356).

9 Judgment of the CJEU in Case C-128/17 (ECLI:EU:C:2019:194), concerning action for annulment under Article 263 TFEU of the NEC Directive (the applicant was the Republic of Poland, supported by Hungary and Romania). Some of the applicant's arguments were as follows:

a) claim that "the Parliament and the Council infringed the principles of sincere cooperation, transparency and openness" e.g. through negotiations on the national emission reduction commitments that, in Poland's view, were discriminatory and opaque;

b) complaint against the infringement of the proportionality principle, manifested in the contested directive imposing a heavier burden on Poland than on the other Member States.

10 I have omitted international agreements concerning the issue under discussion, namely so-called emission law, noise protection, ozone layer protection, electromagnetic radiation protection, as well as emission trading, or the issue or renewable energy sources. All these could jointly be labelled as "air protection".

11 See more broadly: Marek Górski, ed., Prawo ochrony środowiska, Warsaw: Wolters Kluwer, 2018; Ewa Radecka, Filip Nawrot, ed., Prawne instrumenty ochrony powietrza. 


\section{COMMITMENTS ARISING FROM THE NEC DIRECTIVE}

The directive imposed a number of obligations on Member States, including Poland. Among those obligations are:

a) the requirement to draw up, adopt and implement a variety of instruments to reduce air pollution (particularly important in this regard is the national air pollution control programme) and monitor anthropogenic emissions ${ }^{12}$;

b) the requirement to prepare and annually update national emission inventories and national emission projections (which must be transparent, consistent, comparable, complete, and accurate), as well as informative inventory reports (IIR) ${ }^{13}$;

c) the requirement to limit anthropogenic emissions of sulphur dioxide (SO2), nitrogen oxides (NOX), non-methane volatile organic compounds (NMLZO), ammonia (NH3) and fine particulate matter (PM2,5).

Given the thematic scope of this article, the next part focuses predominantly on Article 6 of the NEC Directive, pursuant to which each Member State shall draw up, adopt and implement their respective national air pollution control programmes in order to fulfil their commitments to limit emissions, and contribute to achieving the objectives concerning air quality. The programme shall be updated periodically. The document is intended to coordinate and manage actions and measures carried out in accordance with other documents, and to establish foundations to create further policies and strategies involving enhanced efforts to accomplish the emission reduction objectives. An important element of the NAPCP is

Wybrane zagadnienia, Katowice: Grupa Infomax, 2018; Bartosz Rakoczy, ed., Prawne aspekty ochrony powietrza, Toruń: Polskie Zrzeszenie Inżynierów i Techników Sanitarnych, 2018; Janina Ciechanowicz-McLean, Prawo ochrony klimatu, Warsaw: Powszechne Wydawnictwo Prawnicze, 2016; Marcin Popkiewicz, Aleksandra Kardaś, Szymon Malinowski, Nauka o klimacie, Warsaw: Sonia Draga sp. z o.o., 2018.

12 Member States shall ensure the monitoring of negative impacts of air pollution upon ecosystems based on a network of monitoring sites that is representative of their freshwater, natural and semi-natural habitats and forest ecosystem types, taking a cost-effective and risk-based approach.

${ }_{13}$ See more broadly: Article 8 of the NEC Directive. 
coherence and synergy with other plans, programmes, and policies, which will help to implement actions and measures in a cost-effective manner.

The Directive imposes on Member States the obligation to ensure dissemination to the public of the information on national air pollution control programmes and any updates. What is important, Member States should make these programmes and updates subject to consultation with the public and competent authorities at all levels. The document should be drawn up based on, among other things, knowledge on the projected changes in emissions, which will enable the best possible adjustment of the measures and strategies envisaged in the programme and intended to reduce emissions. The minimum content of NAPCP is laid down in Annex III part I to the Directive. Furthermore, in accordance with the NEC Directive, the European Commission shall specify, by means of implementing acts, the format of the national air pollution control programmes ${ }^{14}$.

As pointed out in the NEC Directive, the objectives, i.e. the fulfilment of national commitments regarding limiting emissions, should be realized through limiting air pollution at its source, which will result in an effective and permanent reduction in air pollutions. The scope of emission reductions covers two periods, which encompass the following years: 2020 to 2029, and from 2030 onwards. Emission reduction commitments are determined by reference to emissions in the reference year 2005. These commitments have been set for Poland for the periods referred to above at: for $\mathrm{SO} 2$ - by $59 \%$ and $70 \%$, respectively; for NOX - by $30 \%$ and $39 \%$; for NMLZO - by $25 \%$ and $26 \%$; for NH3 - by $1 \%$ and $17 \%$; and for PM2,5 - by $16 \%$ and $58 \%$.

By the way, it is worth noting that Member States have, to varying degrees, complied with their obligation to submit to the Commission

14 The format of the national air pollution control programme was specified in the Commission Implementing Decision (EU) 2018/1522 of 11 October 2018 laying down a common format for national air pollution control programmes under Directive (EU) 2016/2284 of the European Parliament and of the Council on the reduction of national emissions of certain atmospheric pollutants (OJ L 2018.256/87). Also important in this context are the guidelines on the elaboration of national air pollution control programmes under the Directive (EU) 2016/2284 of the European Parliament and of the Council of 14 December 2016 on the reduction of national emissions of certain atmospheric pollutants (OJ C 77, 1.3.2019, pp. 1-33). 
the first national air pollution reduction programs. This obligation under Article 10(1) of the NEC Directive had to be fulfilled by Member States by 1 April 2019. However, according to data on the Commission's official website, only 6 countries met this deadline. It is significant that there are also countries which have not submitted the relevant documents proving the fulfilment of the reporting obligation under the Directive.

An interesting issue, which may be the subject of a separate and extensive analysis, is the issue of comparing the legislation of other countries in this area. This, however, goes beyond the framework of this study and is significantly hampered by the fact that the detailed results of the Commission's analysis of national air pollution reduction programs will be available by 1 April 2020 (in accordance with Article 11 of the NEC Directive).

\section{THE NATIONAL AIR POLLUTION CONTROL PROGRAMME}

\section{IN LIGHT OF NATIONAL AIR PROTECTION MEASURES OF A PLANNING NATURE ${ }^{15}$ ARISING FROM ENVIRONMENTAL PROTECTION LAW}

The key legislation that has to be invoked here is the Environmental Protection Law, which provides for two instruments of a planning/programmatic nature. These are as follows:

1) the national air protection programme (further: NAPP);

2) short-term action plan ${ }^{16}$.

15 The classification of air protection instruments into economic, organizational and regulatory, follow e.g. from a publication by Grzegorz Dobrowolski, Ochrona powietrza: zagadnienia administracyjnoprawne, Kraków: Zakamycze, 2000, where the author in organizational instruments includes those arising from the Planning and Spatial Management Act.

It is worth noting that pursuant to Article 8 of the Act of 27 April 2001 - Environmental Protection Law (uniform text JL of 2019, item 1396, as amended, further: EPL), policies, strategies, plans or programmes relating in particular to industry, energy, transport, telecommunications, water management, waste management, land-use planning, forestry, agriculture, fisheries, tourism and land use shall take into account the principles of environmental protection and sustainable development. What is important, the above list of disciplines is not exhaustive and merely offers examples.

16 See e.g. resolution of the Assembly of Silesian Voivodship of 18 December 2017 (No. V/47/5/2017111) on the adoption of the Air Protection Programme for Silesian 
The national air protection programme may be developed when the maximum levels permitted or the target levels of substances in ambient air are exceeded in a large part of the country, and the measures undertaken by local government authorities and bodies do not result in reducing pollutant emissions to the air. The minister responsible for the environment may draw up the national air protection programme, which is a strategic document laying down the goals and lines of action that should be pursued in air protection programmes.

The programme is announced in the Official Journal of the Republic of Poland (Monitor Polski) together with a communication specifying the address of the web page on which the programme was posted and the date on which it becomes effective (Article 91c of the EPL) ${ }^{17}$.

It should be noted at this point that elaboration of the NAPP is not mandatory, as shown by the use of the word "may" in the wording of the provision. Secondly, what is symptomatic, this is merely a strategic document, and does not belong to any category of legal act ${ }^{18}$.

The other instrument - the short-term action plan $^{19}-$ is a type of a restorative programme put into force when the alert levels, maximum

Voivodship, designed to achieve the thresholds for air-borne substances and to establish the exposure concentration obligation.

17 A communication of the Minister of the Environment of 17 September 2015 was published in Monitor Polski, stating that the programme in question had been developed ("National Air Protection Programme until 2020, with a perspective until 2030") and would become applicable as of 1 October 2015 (November 5, 2019, http://prawo.sejm.gov.pl/isap. nsf/DocDetails.xsp?id=WMP20150000905). The key objective laid down in the NAPP "is improving the quality of air across Poland. This applies in particular to areas with the highest concentration of air pollutants, as well as largely populated areas. Air quality should improve at least to a level where it does not pose a threat to human health, in compliance with the requirements of the European Union legislation transposed into the Polish legal system, and in the 2030 perspective - to thresholds set by the World Health Organisation".

18 On 24 October 2018, a Deputies' Bill on Amendment of the Environmental Protection Law was submitted at the Sejm of the Republic of Poland (Sejm papers No. 2986, http:// www.sejm.gov.pl/sejm8.nsf/PrzebiegProc.xsp?id=31D75194FA3C9099C125833E004EDAEA). The proposed amendment concerns Article 91c of the EPL and changing the status of the NAPP from optional to mandatory.

19 See more broadly: Anna Dubowska, Plan działań krótkoterminowych jako prawny instrument ochronypowietrza, Przegląd Prawa Ochrony Środowiska 2(2015): 95-110; Ryszard Mikosz, Bezczynność sejmiku województwa w sprawie planu działań krótkotermi- 
levels permitted or target levels of substances in ambient air are exceeded in a specific area (Article 92(1) of the EPL). When this is the case, the province (voivodship) government, within 12 months from the receipt of information on this risk from the Chief Environmental Protection Inspector, draws up and submits for opinion of relevant commune heads, town or city mayors, as well as poviat (county) starosta draft resolution on a shortterm action plan. The provincial assembly, within 15 months following the receipt of information from the Chief Environmental Protection Officer, lays down, by way or a resolution, a short-term action plan.

The short-term action plan should in particular encompass:

1) a list of entities using the environment, obliged to reduce or stop releasing into the air gas and dust from installations;

2) the organization and restriction or prohibition of the movement of vehicles and other internal combustion engine-driven devices;

3) manner of proceeding for authorities, institutions, and entities using the environment, as well as behaviour of citizens in the event of exceedances;

4) the mode and manner of announcement of exceedances.

It is also worth mentioning, although to a limited extent, that on 14 June 2019 the Regulation of the Minister for the Environment on air protection programs and short-term action plan $s^{20}$ was issued, which extends the content of air protection programs in relation to the previously binding implementing act. This legal act defines:

1) specific requirements to be met by air quality programs and shortterm action plans;

2) the form in which air quality programs and short-term action plans as well as necessary components thereof shall be drawn up;

3) the range of issues to be identified and assessed in the air quality programs and action plans.

The Regulation significantly emphasizes the information obligations of authorities, which is underlined both in the text of the implementing act itself (e.g. $\$ 3(5)$ of the Regulation or point 4 of the Annex to the Reg-

nowych, In: Prawne instrumenty ochrony powietrza. Wybrane zagadnienia, Ewa Radecka, Filip Nawrot, ed., Katowice: Grupa Infomax, 2019: 52-64.

20 JL of 2019, item 1159. 
ulation, which indicates the obligation to inform the public about the risk of exceeding the alert, limit or target levels of substances in the air and about the occurrence of such exceedances).

The Appendix to the abovementioned legal act sets out examples of possible short-term actions and constraints resulting from the short-term action plan. These activities are divided, according to the reduction of emissions, as follows:

a) surface emission (e.g. a temporary ban on smoking in fireplaces if they are not the only source of heating for the dwelling during the heating period);

b) linear emission (e.g. transfer of heavy traffic to alternative sections designated by road managers in the area) and

c) point emission (temporary reduction of production in installations having a negative impact on air quality, as indicated in the plan, excluding large combustion installations for the supply of electricity and heat).

\section{NATIONAL PROGRAMME FOR AIR POLLUTION CONTROL ADOPTED IN POLAND ${ }^{21}$}

With reference to the general principles governing the validity of secondary legislation in the national legal order, it is legitimate to stress that the Directive imposes on Member States the obligation to fully incorporate the EU's requirements into their respective legal and administrative systems, but allows them discretion in selecting the means for the fulfilment

21 It should be stressed how very quickly the legislative works on the adoption of this programme proceeded. The draft version was submitted for interministerial consultations on 1 February 2019, followed by - put very briefly - social consultations, proceedings at the Committee for European Affairs, Standing Committee of the Council of Ministers, and was finally submitted to the Council of Ministers, where it was adopted on 29 April 2019 (November 5, 2019, https:/bip.kprm.gov.pl/kpr/wykaz/r1118957287, Projekt-uchwaly-Rady-Ministrow-w-sprawie-przyjecia-Krajowego-programu-ograniczan. html; https://bip.mos.gov.pl/pl/prawo/inne-projekty/krajowy-program-ograniczania-zanieczyszczenia-powietrza-projekt/). 
of this obligation ${ }^{22}$. Pursuant to Article 20 of the NEC directive, "Member States shall bring into force the laws, regulations and administrative provisions necessary to comply with this Directive by 1 July 2018”. In Poland, this transposition was effected by amendment of the act on greenhouse gas emission trading and some other acts ${ }^{23}$, which - as should be particularly stressed - only took place as late as the summer of 2019. Such proceedings may result in the implementation of a procedure to hold a Member State liable for infringements of its obligations under Articles 258 and 260 of the Treaty on the Functioning of the European Union ${ }^{24}$.

Article 10 of the NEC Directive imposed on Member States the obligation to provide their first national air pollution control programmes to the Commission by 1 April $2019^{25}$. Poland failed to deliver this on time ${ }^{26}$,

22 Marek Górski, Magdalena Michalak, In: Prawo ochrony środowiska, Marek Górski, ed., Warsaw: Wolters Kluwer, 2018: 46; Aleksander Gubrynowicz, Ochrona powietrza w świetle prawa międzynarodowego, Warsaw: Liber, 2005 (in particular the notes from Chapter IX. Airprotection in the light of European Union standards); Marek Górski, Prawna ochrona jakości środowiska jako element działań na rzecz rozwoju zrównoważonego (na przykładzie przepisów o ochronie jakości powietrza), In: Międzynarodowe prawo ochrony środowiska XXI wieku, Aleksander Gubrynowicz, Zdzisław Galicki, ed., Warszawa: Stowarzyszenie Absolwentów Wydziału Prawa i Administracji Uniwersytetu Warszawskiego, 2013, 233-255.

23 Introduction of Article $16 \mathrm{~b}$ to the Act of 17 July 2009 on the management of greenhouse gases and other substances (further: AMGHG) through Article 12 point 13 of the Act of 4 July 2019 amending the greenhouse gas emission trading act and some other acts (JoL of 2019, item 1501; the amendments entered into force on 24 August 2019).

24 JoL of 2004, No. 9, item 864/2 as amended. See more details: Nina Półtorak, In: Traktat o funkcjonowaniu Unii Europejskiej, komentarz do art. 260 Traktatu o Funkcjonowaniu Unii Europejskiej, Andrzej Wróbel, Dagmara Kornobis-Romanowska, Justyna Łacny, ed., LEX; Ewa Radecka, Wyrok Trybunału Sprawiedliwości Unii Europejskiej z dnia 22 lutego 2018 r. w sprawie C336/16 Komisja Europejska vs. Rzeczpospolita Polska - konsekwencje prawne, In: Prawne instrumenty ochrony powietrza. Wybrane zagadnienia, Filip Nawrot, Ewa Radecka, ed., Katowice: Grupa Infomax, 2018, 97-108.

25 Information on how other Member States fulfilled this obligation can be found here: https://cdr.eionet.europa.eu/ReportekEngine/searchdataflow?dataflow_uris=http\%3A \%2F\%2Frod.eionet.europa.eu\%2Fobligations\%2F753\&years\%3Aint\%3Aignore_empty $=\&$ partofyear $=\&$ reportingdate_start $\% 3$ Adate $\% 3$ Aignore_empty $=\&$ reportingdate_ end $\% 3$ Adate\%3Aignore_empty=\&country=\&release_status=released \&sort_on=reportingdate\&sort_order=reverse\&batch_size $=$.

26 This could have been due to awaiting the issuance of the CJEU judgment declaring invalidity of the NEC Directive in Case C-128/17 (ECLI:EU:C:2019:194) or - more like- 
as the NAPCP was adopted by Resolution No. 34 of the Council of Ministers of 29 April 201927, and only entered into force on 22 June 2019. The aforementioned resolution did not specify any legal grounds for the issuance of this act. This gives rise to the general observation that the NAPCP was issued first (April 2019), and the legal framework for these types of measures was only created in the national legal system afterwards (2019), including the clarification that these programmes are adopted by way of a resolution of the Council of Ministers ${ }^{28}$.

The minimum content of the NAPCP is laid down in detail in Article $16 \mathrm{~b}(3)$ of the AMGHG ${ }^{29}$. The process of elaboration of the NAP$\mathrm{CP}$ must include participation of the public under the conditions and according to the procedure laid down in the Act of 3 October 2008 on the Provision of Information on the Environment and its Protection, Public Participation in Environmental Protection and Environmental Impact Assessments $^{30}$ (which constitutes fulfilment of the obligation imposed by Article 6 point 5 of the NEC Directive). Pursuant to the applicable provisions of Polish law, the programme ought to be revised and updated at least every 4 years (which is in line with the provisions of Article 6 point 3 of the NEC Directive).

ly - awaiting the issuance of guidelines on the elaboration of national air pollution control programmes (these were published on 1 March 2019).

27 Official Journal of the Republic of Poland (Monitor Polski), item 572.

28 See Article 16b(8) of the AMGHG.

29 The NAPCP shall at least cover:

1) the national air quality and pollution policy framework in which context the programme has been developed, including;

2) the policy options considered to comply with the emission reduction commitments for the period between 2020 and 2029 and for 2030 onwards and the intermediate emission levels determined for 2025 and to contribute to further improve the air quality, and their analysis, including the method of analysis; where available, the individual or combined impacts of the policies and measures on emission reductions, air quality and the environment and the associated uncertainties;

3) the emissions reduction trajectory determined as the indicative emissions reduction levels and national emission reduction commitments referred to in Article 16a;

4) the measures and policies selected for adoption, including a timetable for their adoption, implementation and review and the competent authorities responsible.

30 Uniform text JoL of 2018, item 2081, as amended. 
As for the content and wording of the Polish NAPCP, it puts a strong emphasis on links with other documents, especially with the draft [highlight added: Ewa Radecka] energy policy for Poland until 2040 31 (EPP2040) ${ }^{32}$. The very fact that this link is made so prominent raises doubts due to the highly optimistic and ambitious plans laid down in the EPP2040. The draft provides for reaching $21 \%$ of renewable energy sources in final energy consumption by 2030 , accompanied by a simultaneous decrease in the use of on-shore wind farms and increase in the use of off-shore wind power. According to the EPP2040 draft, by 2040, the majority of renewable energy will come from photovoltaics and off-shore wind turbines ${ }^{33}$. The projections for energy sources in 2040 are as follows: $32 \%$ coal, $34 \%$ renewable energy sources and waste, $16 \%$ gas, and as much as $18 \%$ (sic!) atomic energy ${ }^{34}$.

Achieving these levels does not seem realistic, if only in the context of Poland failing to achieve at least $15 \%$ of renewable energy in gross final energy consumption by $2020^{35}$, including at least $10 \%$ share of renewable

31 November 5, 2019, https:/www.gov.pl/web/energia/polityka-energetyczna-polski- do-2040-r-zapraszamy-do-konsultacji1.

32 See p. 11 of the NAPCP, where the EPP2040 was referred to as the key [highlight added: Ewa Radecka] document taken into consideration for determination of lines of intervention in the area of reduction of air pollution.

33 Rightly so, as producing energy from a renewable source like wind energy has been, due to the complexity of legal regulations, almost impossible in Poland. See e.g. M. Makowski, Ustawa o inwestycjach w zakresie elektrowni wiatrowych. Komentarz, Wprowadzenie, legal status as of 20 September 2018, LEX; EwaRadecka, Filip Nawrot, The Implementation of the Paris Agreement in Poland. Theory and Practice, Review of European and Comparative Law 2019, 36(1): 27-42, https://doi.org/10.31743/recl.4737.

34 November 7, 2019, https://wysokienapiecie.pl/14959-polityka-energetyczna-2040 -pobozne-zyczenia-w-sprawie-wegla-atomu/.

35 According to a Supreme Audit Office report: "Achieving the adopted target of $15 \%$ of renewable energy sources in total gross energy consumption in 2020 may be at risk. In 2016, the share only marginally exceeded $11 \%$ and was at its lowest since 2013 ". The Supreme Audit Office points out that the development of the renewable energy industry in Poland has been adversely affected by e.g. absence of the state's consistent policy towards renewable energy sources, delays in the issuance of implementing acts and absence of a stable and friendly legal environment that would ensure safety and predictability of renewable energy investments, especially in the electric energy sector" (November 5, 2019, 
energy used in transportation ${ }^{36}$. Putting so much faith in atomic energy does not appear justifiable, either, if only due to the lengthy procedures and ever-changing date of the launch of Poland's first nuclear power plant ${ }^{37}$.

It is also difficult to confirm in the applicable provisions of Polish law implementation of Article 18 of the NEC Directive, which states that, "Member States shall lay down the rules on penalties applicable to infringements of national provisions adopted pursuant to this Directive and shall take all measures necessary to ensure that they are implemented. The penalties provided for shall be effective, proportionate and dissuasive.

Turning to detailed analyses, it is worth referring to at least some of the contents of NAPCP. The five-chapter document contains a wide range of considerations concerning, among others:

- national air quality and air pollution policy frameworks;

- progress made under current policies and measures to reduce emissions and improve air quality and the extent to which national and EU commitments are being met compared to 2005;

- policy options considered to comply with the emission reduction commitments set for 2020 and 2030 and the medium-term emission levels set for 2025;

- the projected combined effects of policies and measures (scenario with additional measures) on emission reductions, air quality at home and in neighboring Member States, the environment and related uncertainties.

https://www.nik.gov.pl/najnowsze-informacje-o-wynikach-kontroli/zielona-energia-dostala-zadyszki.html).

36 See Article 3 of the Directive 2009/28/EC of the European Parliament and of the Council of 23 April 2009 on the promotion of the use of energy from renewable sources and amending and subsequently repealing Directives 2001/77/EC and 2003/30/EC (OJ L 140, 5.6.2009, pp. 16-62).

37 According to the Polish Nuclear Power Programme (adopted by Resolution No. 15/2014 of the Council of Ministers of 28 January 2014 on a multiannual programme entitled "Polish Nuclear Power Programme"; Official Journal of the Republic of Poland (Monitor Polski), item 502), the construction of Poland's first nuclear power plant was supposed to be completed on 31 December 2020 (around 6000 MW by 2020 and another 6000 MW by 2030). 
The document notes that exceeding of PM10 and PM2.5 particulate matter and benzo(a)pyrene in winter and too high concentrations of tropospheric ozone in summer remain an important problem. As far as the winter season is concerned, a significant contribution to poor air quality is attributed mainly to the domestic and municipal sector, i.e. the problem of the so-called low emissions ${ }^{38}$.

\section{CONCLUSIONS}

To conclude, one should speak disapprovingly of the manner of legislation that was presented in the case discussed here and that is an example of utmost ignorance on the part of the legislature.

Secondly, the NAPCP does not constitute a generally applicable law and, given the form in which it is adopted, cannot be grounds for specific solutions conferring rights or imposing obligations. Indeed, government's resolutions, as internal law acts, cannot be grounds for the issuance of administrative decisions or court judgments involving citizens or legal persons. Pursuant to Article 93(1) of the Constitution of the Republic of Poland, resolutions of the Council of Ministers and orders of the Prime Minister and ministers shall be of an internal character and shall bind only those organizational units subordinate to the organ which issues such $\mathrm{act}^{39}$. This leads to the conclusion that the legislature did not learn from the prevailing criticism of the form in which the National Air Protection Programme is adopted.

Thirdly, such a strong link between the NAPCP and the overly optimistic draft of Poland's energy policy until 2040 must be considered a step leading to overestimation of faith put in the NAPCP.

Fourthly, late transposition may lead to appropriate legal results with financial consequences for Poland. Moreover, the correctness of this trans-

38 The issue of lowemissions was the subject of consideration, e.g. Ilona Przybojewska, Problem niskiej emisji i dostępne rozwiązania prawne, Europejski Przegląd Sądowy 7(2017): 39-49.

39 See Article 111 of the Nature Conservation Act of 16 April 2004 (uniform text JoL of 2018, item 1614, as amended) and the programme for the conservation and sustainable use of biodiversity (adopted by a resolution of the Council of Ministers). 
position will also be assessed. Both of these situations may result in the implementation of procedure under Article 258 of the Treaty on the Functioning of the European Union and, in the thelonger term, Article 260, as well as the imposition of a periodic penalty payment and/or a lump sum payment ${ }^{40}$.

All of the above triggers the overall pessimistic reflection that the NAP$\mathrm{CP}$ is yet another extensive instrument, programmatic and internal in nature, that does not make an actual and effective contribution to the fight for clean (or cleaner) air.

\section{REFERENCES}

Ciechanowicz-McLean, Janina. 2016. Prawo ochrony klimatu, Warsaw: Powszechne Wydawnictwo Prawnicze.

Dobrowolski, Grzegorz. 2000. Ochrona powietrza: zagadnienia administracyjnoprawne, Kraków: Zakamycze.

Dubowska, Anna. 2015. Plan działań krótkoterminowych jako prawny instrument ochrony powietrza, Przegląd Prawa Ochrony Środowiska 2: 95-110.

Górski, Marek, ed. 2018. Prawo ochrony środowiska, Warsaw: Wolters Kluwer.

Górski, Marek. 2013. Prawna ochrona jakości środowiska jako element działań na rzecz rozwoju zrównoważonego (na przykładzie przepisów o ochronie jakości powietrza), In: Międzynarodowe prawo ochrony środowiska XXI wieku, Aleksander Gubrynowicz, Zdzisław Galicki, ed., 233-255, Warszawa: Stowarzyszenie Absolwentów Wydziału Prawa i Administracji Uniwersytetu Warszawskiego.

Gubrynowicz, Aleksander. 2005. Ochrona powietrza w świetle prawa międzynarodowego, Warsaw: Liber.

Makowski, Marcin. 2018. Ustawa o inwestycjach w zakresie elektrowni wiatrowych. Komentarz, W prowadzenie, legal status as of 20 September 2018, LEX. Przybojewska, Ilona. 2017. Problem niskiej emisji i dostępne rozwiązania prawne, Europejski Przegląd Sądowy 7 (2017): 39-49.

Radecka, Ewa, Nawrot, Filip, ed. 2019. Prawne instrumenty ochrony powietrza. Wybrane zagadnienia, Katowice: Grupa Infomax.

40 See judgment of the Court of 15 October 2015 in Case C-167/14 Commission v. Greece (ECLI:EU:C:2015:684). 
Radecka, Ewa, Nawrot, Filip. 2019. The Implementation of the Paris Agreement in Poland. Theory and Practice, Review of European and Comparative Law 36(1): 27-42, https://doi.org/10.31743/recl.4737.

Radecka, Ewa. Wyrok Trybunału Sprawiedliwości Unii Europejskiej z dnia 22 lutego 2018 r. w sprawie C336/16 Komisja Europejska vs. Rzeczpospolita Polska - konsekwencje prawne, In: Prawne instrumenty ochrony powietrza. Wybrane zagadnienia, Ewa Radecka, Filip Nawrot, ed., 97-108, Katowice: Grupa Infomax, 2018.

Rakoczy, Bartosz, ed. 2018. Prawne aspekty ochrony powietrza, Toruń: Polskie Zrzeszenie Inżynierów i Techników Sanitarnych.

Popkiewicz, Marcin, Kardaś, Aleksandra, Malinowski, Szymon. 2018. Nauka o klimacie, Warsaw: Sonia Draga sp. z o.o.

Półtorak, Nina. 2012. In: Traktat o funkcjonowaniu Unii Europejskiej, komentarz do art. 260 Traktatu o Funkcjonowaniu Unii Europejskiej, Andrzej Wróbel, Dagmara Kornobis-Romanowska, Justyna Łacny, ed., LEX.

Mikosz, Ryszard. 2019. Bezczynność sejmiku województwa w sprawie planu działań krótkoterminowych, In: Prawne instrumenty ochrony powietrza. Wybrane zagadnienia, Ewa Radecka, Filip Nawrot, ed., 52-64. Katowice: Grupa Infomax. 
